\title{
First detection of Megaselia scalaris (Loew) (Diptera: Phoridae) as a facultative endoparasitoid of Nezara viridula (L.) (Hemiptera: Pentatomidae)
}

\author{
Magdi Shaaban Ali El-Hawagry ${ }^{1 *}$ (D) Ayman Mohey Eldin Ebrahim² and Maha Salah Eldin Nada ${ }^{3}$
}

\begin{abstract}
Background: The phorid fly Megaselia scalaris (Loew) (Diptera: Phoridae) is an omnivorous species, capable of exploring a large variety of environments and ecological niches. It is known as an important detritivore species with maggots feeding on a variety of food of both animal and plant origin.

Results: The present study reports M. scalaris as an endoparasitoid attacking colonies of the southern green stink bug Nezara viridula (L.) for the first time. This case of parasitism was observed inside rearing cages of $\mathrm{N}$. viridula at the Plant Protection Research Institute, Dokki, Egypt in August 2020. We firstly identified adult individuals of M. scalaris which were found moving erratically within the cages using relevant identification keys. To verify that $N$. viridula individuals are parasitized by the same parasitoid and they are not infected with other parasitoids, some of the parasitized bugs were transferred to a separate cage at the same laboratory conditions and the developmental stages of the dipteran parasitoid were observed until the adult emergence.

Conclusion: The present investigation revealed that M. scalaris could be included to the recorded parasitoid species of N. viridula, and further studies should be carried out to assess the efficacy of this fly as a biocontrol agent.
\end{abstract}

Keywords: Scuttle fly, Megaselia scalaris, Southern green stink bug, Nezara viridula, Biocontrol agent, Egypt

\section{Background}

Parasitoid is an organism that attacks any developmental stage of its host, characterized by its larvae which grow on or inside the host and always kill it as part of its life cycle (Godfray and Shimada 1999, Machkour-M'Rabet et al. 2015).

M. scalaris (Loew, 1866) is a cosmopolitan small synanthropic fly $(1-6 \mathrm{~mm})$ in the family Phoridae of the order Diptera. Members of this family are commonly known as "scuttle flies" because adults erratically move in rapid bursts with short pauses (Costa et al. 2007). They are also known as "humpbacked flies" due to their

\footnotetext{
* Correspondence: elhawagry@gmail.com; elhawagry@sci.cu.edu.eg ${ }^{1}$ Entomology Department, Faculty of Science, Cairo University, Cairo, Egypt Full list of author information is available at the end of the article
}

humpbacked appearance, and "coffin flies" because adult females are known to dig down two meters deep in order to reach buried corpses and penetrate closed containers such as coffins to lay their eggs (Varney and Noor 2010).

M. scalaris is an omnivorous species, capable of exploring a large variety of environments and ecological niches. It is known as an important detritivore species with larvae (maggots) feeding on a variety of food of both animal and plant origin, and acting as saprophagous, feeding on nourishment from decaying organic matter, sarcophagous, consuming flesh and necrophagous, feeding on corpses or carrion. However, protein food sources are preferred by the females for maturation of their eggs. These feeding habits make this species a 
facultative predator, parasite, and parasitoid on/in other invertebrates under natural and laboratory conditions (Sukontason et al. 2003, Costa et al. 2007, Disney 2008).

$M$. scalaris was reported as a parasitoid of some insect species of agronomic and medical importance, including members of the following orders: Hemiptera (Costa et al. 2007), Orthoptera (De Gregorio and Leonide 1980, Quesada-Béjar et al. 2017), Mantodea (Koch et al. 2013), Lepidoptera (Ulloa and Hernandez 1981, Souza et al. 2020), Diptera (Batista-Da-Silva 2012, Marchiori 2018), and Coleoptera (Harrison and Gardner 1991, Arredondo-Bernal and Trujillo-Arriaga 1994).

Some cases of animal myiasis caused by $M$. scalaris in a rattlesnake were reported in Brazil (Silva et al. 1999), and infestation of frog eggs was reported in Panama (Brown and Horan 2012). Furthermore, facultative and accidental myiases by $M$. scalaris in nasopharyngeal, intestinal, and leg wound were reported in hospitalized patients in Kuwait and Egypt were recorded (Hira et al. 2004, Mazayad and Rifaat 2005).

The egg of M. scalaris is small and boat-shaped. It is characterized by its gunwale-like palisade of flat platelets that surround the respiratory plastron with its scattered tubercles. Eggshells are more resistant towards unfavorable factors such as bacteria attack and dryness (Wolf and Liu 1996, Disney 2008). The larva (maggot) of $M$. scalaris is almost creamy white and undergoes two molts leading to three larval instars. The first and second larval instars measure $0.75-2 \mathrm{~mm}$ in length, cylindrical, narrowed toward the head, with two cephalic lobes are found on cephalic region and six sensory papillae positioned tangential to the antenna (Boonchu et al. 2004). The third larval instar is similar to the first and second ones. However, it is usually more than $2 \mathrm{~mm}$ in length with spiracular hairs appearing centrally at the constriction of the slender spiracular plates (Sukontason et al. 2002), and this instar can be subdivided into two stages, feeding stage and post-feeding stage (Greenberg, 1991). Pupa of M. scalaris is dorsoventrally flattened with an invaginated cephalic segment, with a pair of long and slender pupal respiratory horns at the end of the fifth dorsal segment. Several spiral papillae are arranged on the respiratory surface of these horns. The papillae are oval and domed-shaped with a single longitudinal straight aperture on them. There is an invaginated cephalic segment with a pair of antennae at the ventral part. A pair of round anterior spiracles is found dorsolateral on the prothorax (Sukontason et al. 2005). The adult $M$. scalaris is small (1-6 $\mathrm{mm}$ in length) with a humpbacked appearance, it can be distinguished by the following characters: Frons brownish-yellow, with dense fine microsetae; scutum brown dorsally; scutellum pale brownish-yellow, with two pair of bristles; costa extends more than half wing length, vein $R_{2}+3$ present; legs long, yellowish in color; mid-tibia without paired bristles; hind tibia without differentiated antero-dorsal hairs, with a dorsal hair palisade; hind femur with a brown tip; abdominal tergites dark brown with yellowish markings; palps straw yellow; tip of anal tube with feathered bristles (Alam et al. 2016, Zhang et al. 2017).

M. scalaris was recorded from Egypt (Steyskal and ElBialy 1967). Abdel-Gawad (2018) and Ismail (2018) reared it in Ain Shams University, Cairo, Egypt, for morphological studies. However, no extensive taxonomic or faunistic studies have been carried out to indicate the exact distribution of this species or its relative phorid species in Egypt.

The southern green stink bug, Nezara viridula (Linnaeus, 1758) (order Hemiptera: family Pentatomidae), is a cosmopolitan bug species distributed throughout the tropical and sub-tropical regions of Africa, America, Asia, and Europe. This bug is considered as one of the most important damaging pests all over the world. It is a highly polyphagous insect, attacking a wide range of grain, fruit, and vegetable crops including beans, cabbage, citrus, cotton, nuts, rice, sugarcane, and wheat, with a preference for leguminous plants. Adults and nymphs of $N$. viridula feed on plant fluids by piercing plant tissues with their piercing-sucking mouthparts. Adults cause maximum damage attacking all parts of plant including stem, petioles, foliage, flowers, fruits, and seeds. Feeding on flower buds causes premature abscission, and damage to seed pods (Hoffman 1935, Corpuz 1969, Hussain and Saharia 1994, Sudan 2008, Tara and Sharma 2010).

In Egypt, heavy infestations and damaging outbreaks of $N$. viridula were reported on citrus in some Egyptian governorates including Menofieh, Gharbieh, and Sharkieh in October 1973, the infestation was observed also on some adjacent crops as maize, vegetables (especially cabbage) and sesame (Attiah et al. 1974, Ali et al. 1978). According to El Maghrabi (1998) and our observations, this bug is distributed in all Egyptian ecological zones: coastal strip, lower Nile Valley and Delta, Fayoum, Western Desert, Eastern Desert, upper Nile Valley, Sinai, and Gebel Elba. It was detected throughout the year attacking fruits and major field crops including rice (Oryza sativa L.), sugar cane (Saccharum officinarum L.), wheat (Triticum aestivum L.), corn (Zea mays L.), cotton (Gossypium barbadense L.), alfalfa (Medicago sativa L.), clover (Trifolium alexandrinum L.), sesame (Sesamum indicum), okra (Abelmoschus esculentus (L.)), potato (Solanum tuberosum L.), tomato (Solanum lycopersicum L.), faba bean (Vicia faba L.), mango (Mangifera indica L.), and citrus (Citrus spp.).

\section{Methods}

This study is based on hundreds of individuals of all developmental stages of $M$. scalaris found parasitizing the 
southern green stink bug $N$. viridula which was reared at the Department of Piercing and Sucking Insects, Plant Protection Research Institute, Agricultural Research Centre, Dokki, Egypt.

In the present case of parasitism, the adults of $M$. scalaris were first observed in August, 2020 and the study continued for four consecutive months until the end of November 2020. The reared bugs were originally collected from a field cultivated with faba bean at the farm of "Faculty of Agriculture, Cairo University, Giza, Egypt" in October 2018. Female and male adults of M. scalaris (Fig. 1a) were found moving erratically within the cages, while eggs, larvae and pupae (Fig. 1b, c) were observed on or inside the bodies of some dead or parasitized bug individuals. Adult individuals of $M$. scalaris were firstly identified using Disney (1994, 2008). To verify that they are parasitized by the same parasitoid and not infected with other parasitoids, some of the parasitized bugs were transferred to a separate cage at the same laboratory conditions and the developmental stages of the dipteran parasitoid were observed until the adult emergence. After about 1 week, tens of male and female adult individuals of $M$. scalaris emerged in the cage. Some of living or newly dead parasitized bugs were dissected to check the larvae and pupae of the parasitoid within it (Figs. 2, 3, and 4). The parasitoid larvae, pupae, adults, and the parasitized bugs were photographed. Some identified adults of M. scalaris were deposited in two Egyptian collections: the collection of the Entomology
Department, Faculty of Science, Cairo University (Efflatoun Bey's collection) and the Collection of the Ministry of Agriculture, Plant Protection Research Institute, Dokki, Giza.

\section{Results}

The parasitoid: Megaselia (Megaselia) scalaris (Loew, 1866)

\section{Synonyms:}

Aphiochaeta banski Brues, Aphiochaeta circumsetosa Meijere, Aphiochaeta ferruginea Brunetti, Aphiochaeta fissa Becker, Aphiochaeta repicta Schmitz, Aphiochaeta xanthina Speiser, Lioyella plusiivorax Enderlein, Megaselia ferruginea (Brunetti), and Megaselia forticapilla Beyer.

\section{World distribution:}

\section{Cosmopolitan.}

\section{Local distribution:}

According to our observations and available museum specimens preserved in Efflatoun Bey's collection in Cairo University and the Collection of the Ministry of Agriculture in Plant Protection Research Institute, this species was recorded from: Coastal Strip (Alexandria, Mariout); Lower Nile Valley and Delta (Abbassiya, Abu-Ghalib, Gezeira, Giza, Pyramids); Fayoum (Kom Osheem, Sennouris); Western Desert (Wadi El-Natroun). The dates of collection extended from April to December.

The host: Nezara viridula (Linnaeus, 1758) Synonyms:

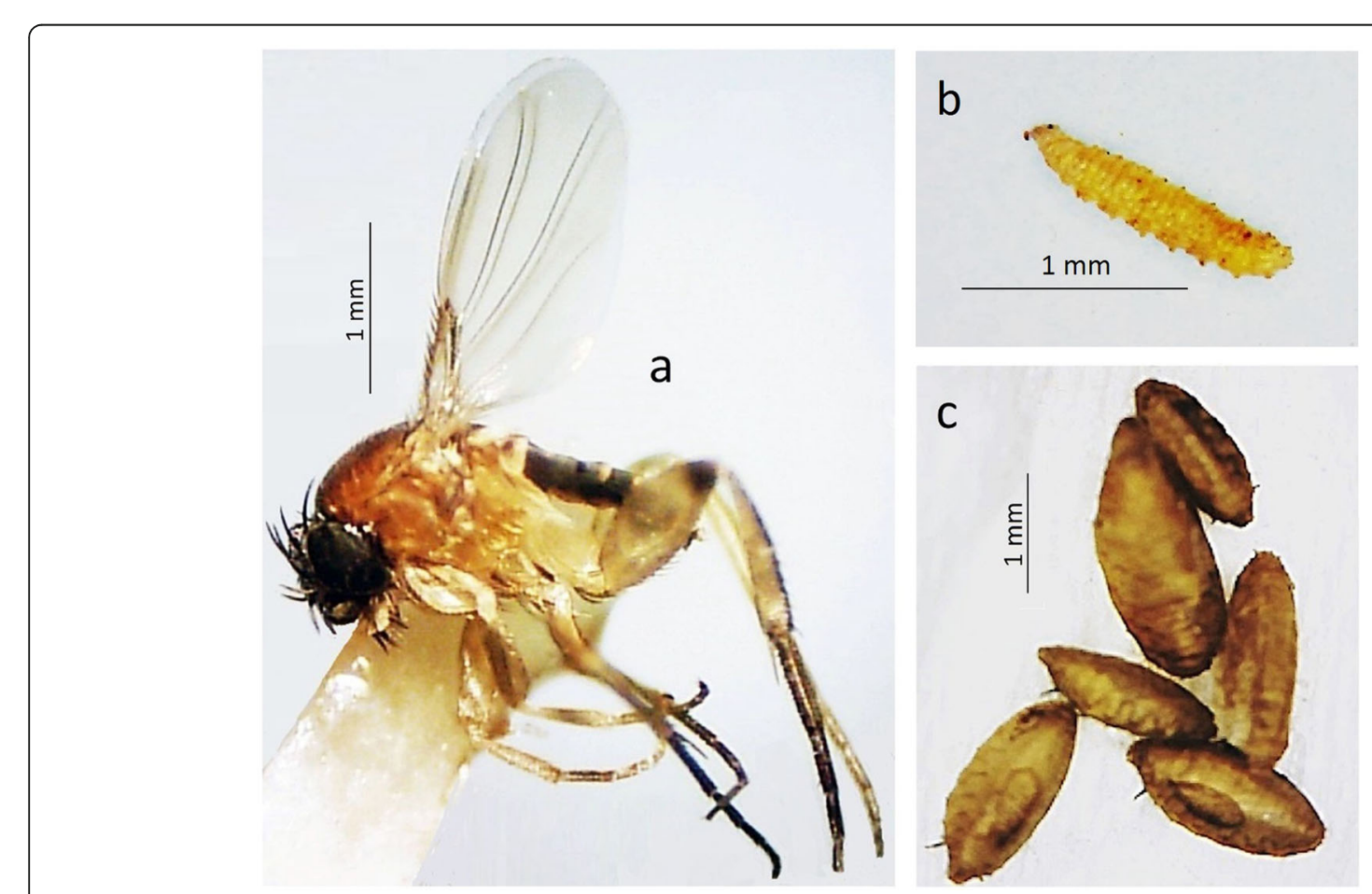

Fig. 1 Megaselia scalaris (Loew). a Adult female, lateral view. b First larval instar. c Pupae 

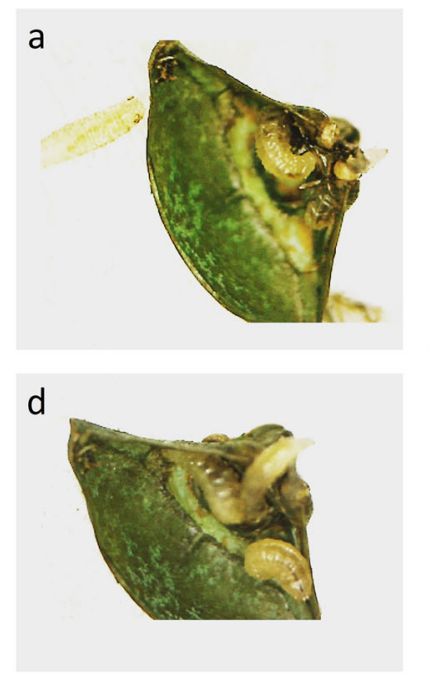

b
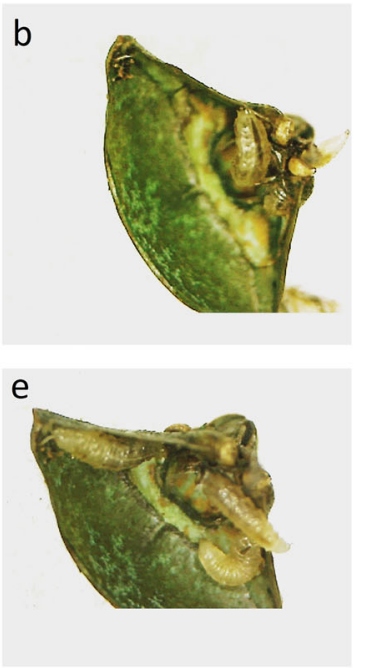

$2 \mathrm{~mm}$
C

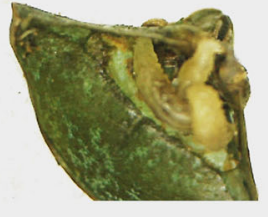

f

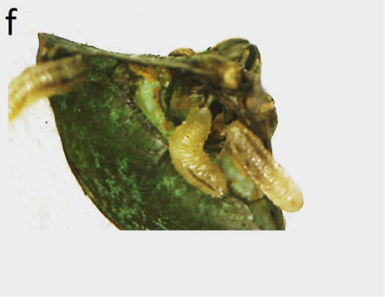

Fig. 2 a-f emergence of third larval instar of Megaselia scalaris from head of Nezara viridula (L.) for pupation

Cimex smaragdulus Fabricius, Cimex viridulus Linnaeus and Nezara smaragdulus (Fabricius).

\section{World distribution:}

Cosmopolitan.

\section{Local distribution:}

According to our observations, El Maghrabi (1998) and museum specimens preserved in Efflatoun Bey's collection in Cairo University and the Collection of the Ministry of Agriculture in Plant Protection Research Institute, this species was recorded throughout the year from different localities representing all Egyptian ecological zones, as follows: coastal strip (Alexandria, Balteem and Burg El-Arab); lower Nile Valley and Delta (Abu-Ghalib, Abu-Katata, Abu-Rawash,
Aga, Ashmoun, Birqash, El-Bustan (Beheira), ElHager, El-Gabal El-Asfar, El-Marg, Gharbieh, Giza, Helwan, Kirdassa, Maadi, Sharkieh, Wardan, Zifta); Eastern Desert (Ismailia, Suez, and Wadi Degla); Western Desert (Bahariya Oasis, Dakhla Oasis, Kharga Oasis, and Wadi El-Natroun); Fayoum (Fayoum City, Kom Osheem, Sennouris, and Tamiya); upper Nile Valley (Assiout, Beni Hussein, Beni Sweif, Edfo, Manfalout, Shandaweil, and Sohag); Sinai (El-Arish); Gebel Elba (Wadi Shallalah).

\section{Observations}

Firstly, many dead individuals of $N$. viridula were noticed by the third author within the rearing cages of the
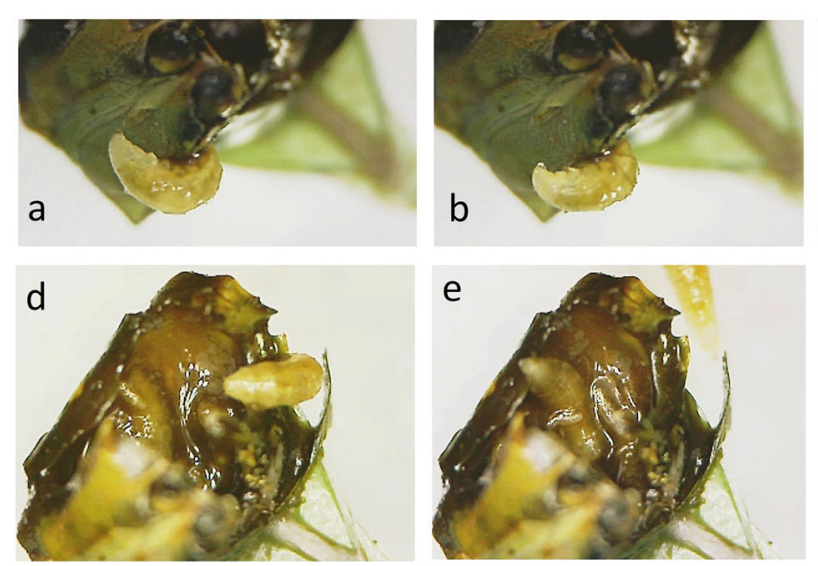

C
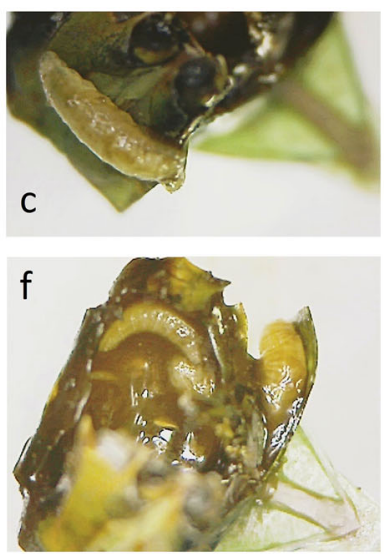

$2 \mathrm{~mm}$

Fig. 3 a-f emergence of third larval instar of Megaselia scalaris from thorax of Nezara viridula (L.) for pupation 

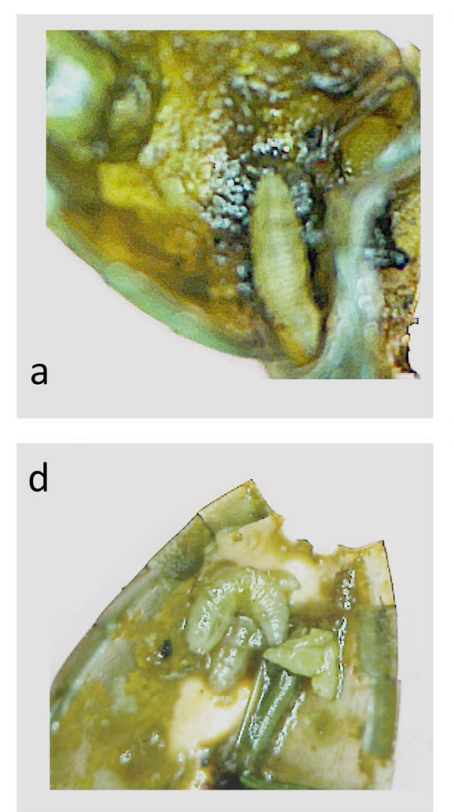
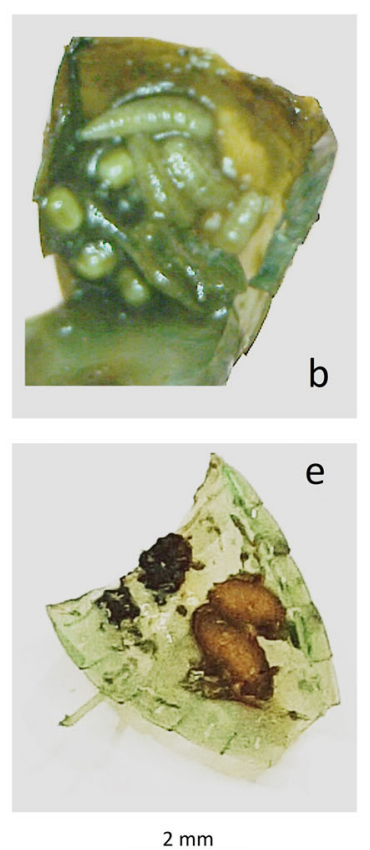
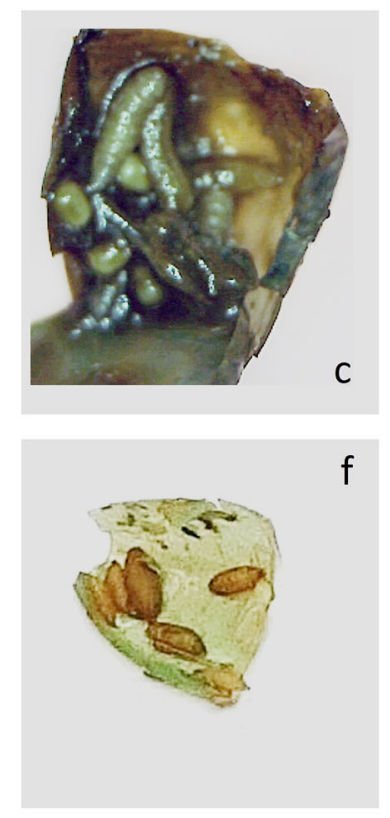

Fig. 4 a-d Third larval instar of Megaselia scalaris inside a dissected abdomen of Nezara viridula (L.). e, f Pupae of Megaselia scalaris inside a dissected abdomen of Nezara viridula (L.)

bug. Since then, we have tried to investigate the cause of this abnormal death. In this regard, we carefully observed and checked the colony. We noticed that all developmental stages of the phorid fly $M$. scalaris were found within the rearing cages of $N$. viridula or on/in the bodies of nymphs and adults of the bug. Consequently, some of the parasitized bugs were transferred to a separate cage at the same laboratory conditions and the developmental stages of the dipteran parasitoid were observed until the adult emergence.

Adults of the fly (Fig. 1a) were found moving erratically within the cages. Eggs were found adhering to head, thorax, and abdomen of the host bug. First instar larvae (Fig. 1b) hatched after 3-5 days at room temperature, about $30{ }^{\circ} \mathrm{C}$, and then they penetrated the bug integument entering its body and feeding on the internal body fluids and tissues for about 1-2 weeks. It seemed that larvae penetrated from the site where they emerged as no specific entrance points were detected. The parasitized bugs usually died after the infection, and mature larvae (third instar) leave their host after completion of the larval stage and emerge outside the host body (Figs. 2 and 3). Mature larvae began to pupate immediately after emergence in soil at the floor of cage. Some larvae may not be able to leave the host bug, so they pupate inside it (Fig. 4e, f). Pupation required about 1 week before adult emergence.

The dissection of living or newly dead parasitized bugs confirmed that larvae of $M$. scalaris developed inside all body regions of the host bug, head (Fig. 2), thorax (Fig. 3), and abdomen (Fig. 4a-d), consuming the internal organs. A large number of larvae was observed in abdomens of dissected bugs, usually more than 40 larvae per abdomen (Fig. 4a-d), while in head and thorax the number was less than 10 larvae in each (Figs. 2 and 3). The internal organs of the parasitized bugs were found destroyed, as no viscera could be found. Other bugs were found semi-destroyed, as only a portion of the digestive system was destroyed. To some extent, thoracic muscle tissues of parasitized bugs showed some destruction. This may interpret why parasitized bugs move with difficulties before death.

\section{Discussion}

The larvae of $M$. scalaris have been described as detritivore, parasite, and parasitoid, consuming a wide spectrum of organic materials of both animal and plant origin (Disney, 2008, Koch et al. 2013).

$M$. scalaris is detected in the present study as a facultative endoparasitoid of the southern green stink bug $N$. viridula for the first time. However, this finding is not surprising as it was reported as a parasitoid of some insect species of agronomic and medical importance, such as the Chagas disease vector Triatoma brasiliensis Neiva [Reduviidae, Hemiptera] (Costa et al. 2007), the grasshoppers Zonocerus variegatus (L.), and Sphenarium purpurascens Charpentier [Pyrgomorphidae, Orthoptera] (De Gregorio and Leonide 1980, Quesada-Béjar et al. 
2017), the mantid Parastagmatoptera tessellata Saussure and Zehntner [Mantidae, Mantodea] (Koch et al. 2013), the pre-pupae of the variegated cutworm or pearly underwing moth Peridroma saucia (Hübner) [Noctuidae, Lepidoptera] (Ulloa and Hernandez 1981), the caterpillars of the hawk moth Isognathus caricae (Linnaeus) [Sphingidae, Lepidoptera] (Souza et al. 2020), the blowflies Chrysomya, and Cochliomyia spp. [Calliphoridae, Diptera] (Batista-Da-Silva 2012), the pupae of the black scavenger fly Palaeosepsis sp. [Sepsidae, Diptera] (Marchiori 2018), the adults of the pecan weevil Curculio caryae (Horn) [Curculionidae, Coleoptera] (Harrison and Gardner 1991) and the rose chafer Macrodactylus murinus Bates [Scarabaeidae, Coleoptera] (ArredondoBernal and Trujillo-Arriaga 1994).

M. scalaris could have a potentiality to control N. viridula side by side with some tachinid flies which have been detected as endoparasitoids of this bug, such as Ectophasia crassipennis (Fabricius) and Trichopoda pennipes (Fabricius) (Cerretti and Tschorsnig 2010, ElHawagry et al. 2020).

\section{Conclusion}

In the present study, the scuttle fly Megaselia scalaris (Loew) (Diptera: Phoridae) was detected as a facultative endoparasitoid of the southern green stink bug Nezara viridula (L.) (Hemiptera: Pentatomidae) for the first time in laboratory colonies of this bug in Egypt. The present investigation revealed that $M$. scalaris could be included to the recorded parasitoid species of $N$. viridula, and further studies should be carried out to assess the efficacy of this fly as a biocontrol agent.

\section{Acknowledgements}

We would like to thank the third author's husband, Mr. Ahmed Eldeeb, Administrative Attaché at the Ministry of Foreign Affairs, Cairo, Egypt, for his invaluable assistance throughout the present study.

\section{Authors' contributions}

ME identified the host fly and drafted the manuscript. AE participated in identifying the host fly. MN reared and observed the host bug, dissected, and photographed some parasitized bugs. All authors participated in the study design and coordination and interpreted the data. All authors have read and approved the manuscript.

\section{Funding}

No funding.

\section{Availability of data and materials}

Data supporting the conclusions of this article are presented in the mainmanuscript.

\section{Ethics approval and consent to participate}

Not applicable.

\section{Consent for publication}

Not applicable.

\section{Competing interests}

The authors declare that they have no competing interests.

\section{Author details}

${ }^{1}$ Entomology Department, Faculty of Science, Cairo University, Cairo, Egypt. ${ }^{2}$ Classification Research Department, Plant Protection Research Institute, Agricultural Research Centre, Ministry of Agriculture, Dokki, Egypt.

${ }^{3}$ Department of Piercing and Sucking Insects, Plant Protection Research Institute, Agricultural Research Centre, Ministry of Agriculture, Dokki, Egypt.

Received: 23 November 2020 Accepted: 28 January 2021

Published online: 05 February 2021

\section{References}

Abdel-Gawad RA (2018) Development rate and ultrastructure changes of puparia of Megaselia scalaris (Loew) (Diptera: Phoridae) induced by Azadirachtin. Egypt Acad J Biolog Sci 11(1):109-120

Alam MS, Ahmed KA, Begum RA, Shahjahan RM (2016) Identification of Megaselia Scalaris (Diptera: Phoridae) based on morphology and mitochondrial 165 rRNA and COI gene sequences. Dhaka Univ J Biol Sci 25(2):149-159

Ali MA, Awadallah AM, El-Rahman AA (1978) The susceptibility of certain citrus varieties to the green stink bug, Nezara viridula (L.) infestation. Proceedings of the Fourth Conference of Pest Control, September 30 - October 3, 1978. (Part I). Academy of Scientific Research and Technology and National Research Centre. Cairo Egypt, 115-122

Arredondo-Bernal HC, Trujillo-Arriaga J (1994) Primer report de Megaselia scalaris (Diptera: Phoridae) como parasitoide de Macrodactylus murinus (Coleoptera: Scarabaeidae). Vedalia 1:27

Attiah HH, Isa AL, Rofail F (1974) An outbreak of Nezara viridula on citrus trees in Egypt. Agric Res Rev 52(1):81

Batista-Da-Silva JA (2012) Phoretic association and facultative parasitoidism between Megaselia scalaris and blowflies, Under Natural Conditions. Online J Biol Sci 12(1):34-37

Boonchu N, Sukontason K, Sukontason KL, Chaiwong T, Piangiai S, Vogtsberger RC (2004) Observations on first- and second-instar larvae of Megaselia scalaris (Loew) (Diptera: Phoridae). J Vector Ecol 29:79-83

Brown BV, Horan RV (2012) A key to Neotropical region frog-egg feeding species of Megaselia (Diptera: Phoridae), with a new species from Panama. Contrib Sci 520:1-4

Cerretti P, Tschorsnig HP (2010) Annotated host catalogue for the Tachinidae (Diptera) of Italy. Stutt Beitr Naturk. Serie A (Biologie) 3:305-340

Corpuz LR (1969) The biology, host range and natural enemies of Nezara viridula (Hemiptera: Pentatomidae). Phillipp Entomol 1:255-259

Costa J, Almeida CE, Esperanc GM, Morales N, Mallet JR, Gonçalves TCM, Prado AP (2007) First record of Megaselia scalaris (Loew) (Diptera: Phoridae) infesting laboratory colonies of Triatoma brasiliensis Neiva (Hemiptera: Reduviidae). Neotrop Entomol 36:987-989

De Gregorio R, Leonide J-C (1980) Un nouveau cas de Phoridé parasite d'Orthoptères adultes. Bull Soc Entomol Fr 85:103-105

Disney RHL (1994) Scuttle flies: the Phoridae. Chapman and Hall, London, UK, p 467

Disney RHL (2008) Natural history of the scuttle fly, Megaselia scalaris. Annu Rev Entomol 53:39-60

El Maghrabi MSS (1998) Field and systematic studied on the family Pentatomidae (Oder Heteroptera) from Egypt. A thesis presented to the Faculty of Science, Cairo University for the award of the Ph.D. degree.

El-Hawagry MSA, Ebrahim AME, Nada MSE (2020) First detection of the Nearctic parasitoid species Trichopoda pennipes (Fabricius) (Diptera: Tachinidae) in Egypt. Egypt J Biol Pest Control 30:12 https://doi.org/https://doi.org/10.1186/ s41938-020-0211-z

Godfray HCJ, Shimada M (1999) Parasitoids as model organism for ecologists. Res Popul Ecol 41:3-10

Greenberg B (1991) Flies as forensic indicators. J Med Entomol 28:565-577

Harrison RD, Gardner WA (1991) Parasitism of the pecan weevil (Coleoptera: Curculionidae) by Megaselia scalaris (Diptera: Phoridae). J Entomol Sci 26: 301-302

Hira PR, Assad RM, Okasha G, Al-Ali FM, lqbal J, Mutawali KE, Disney RH, Hall MJ (2004) Myiasis in Kuwait: Nosocomial infections caused by Lucilia sericata and Megaselia scalaris. Am J Trop Med Hyg 70:386-389

Hoffman WF (1935) The food plants of Nezara viridula. Ann Rev Entomol 34:273292

Hussain S, Saharia D (1994) Susceptibility of some summer green gram cultivars to pod feeders and subsequent damage. J Agri Sci Society of North-East India 7(1):5-8 
Ismail EH (2018) Morphological aberrations induced by Thymol in larvae of Megaselia scalaris L. (Diptera: Phoridae). Egypt J Hosp Med 71(6):3448-3460

Koch NM, Fontanarrosa P, Padró J, Soto I (2013) First record of Megaselia scalaris (Loew) (Diptera: Phoridae) infesting laboratory stocks of mantids (Parastagmatoptera tessellata, Saussure). Arthropods 2:1-6

Linnaeus C (1758) Systema naturae per regna tria naturae, secundum classes, ordines, genera, species, cum caracteribus, differentiis, synonymis, locis, vol 1, 10th edn. L. Salvii, Holmiae [= Stockholm], p 824

Loew H (1866) Diptera Americae septentrionalis indigena. Centuria septima. Berl Entomol Z 10:1-54

Machkour-M'Rabet S, Dor A, Hénaut Y (2015) Megaselia scalaris (Diptera: Phoridae): an opportunistic endoparasitoid of the endangered Mexican redrump tarantula, Brachypelma vagans (Araneae: Theraphosidae). J Arachnol 43(1):115-119. https://doi.org/https://doi.org/10.1636/B14-28.1

Marchiori CH (2018) First occurrence of Megaselia scalaris (Loew) (Diptera: Phoridae) in pupae of Palaeosepsis sp. (Diptera: Sepsidae) in Brazil. Int J Res Pharm Biosci 5:7-9

Mazayad SA, Rifaat MM (2005) Megaselia scalaris causing human intestinal myiasis in Egypt. Egypt Soc Parasitol 1:331-340

Quesada-Béjar V, Nájera-Rincón MB, Reyes-Novelo E, González-Esquivel CE (2017) Primer registro de Megaselia sp. (Diptera: Phoridae) como parasitoide de Sphenarium purpurascens purpurascens (Orthoptera: Pyrgomorphidae). Acta Zool Mex 33(2):407-410

Silva RJ, Prado AP, Rodrigues RR, Lopes CA, Godoy WAC (1999) Megaselia scalaris (Diptera: Phoridae) causing myiasis in Crotalus durissus terrificus (Serpentes: Viperidae) in Brazil. J Med Entomol 36:630

Souza TS, Fernandes VJ, Aguiar-Menezes EL, Resende ALS, Pereira TPL, Gazal VS, Menezes EB (2020) Larvae of Megaselia Róndani, 1856 (Diptera: Phoridae) as parasitoid of Sphingidae (Lepidoptera) and its frugivory on avocado. Entomol Commun 2:ec02020. https://doi.org/https://doi.org/10.37486/2675-1305. ec02020

Steyskal GC, El-Bialy S (1967) A list of Egyptian Diptera with a bibliography and key to families. Min Agric Tech Bull 3:12-18

Sudan M (2008) Survey of insect pests infesting some medicinal plants in district Rajouri ( $\mathrm{J}$ and K). M. Phil. dissertation submitted to University of Jammu, Jammu, India

Sukontason K, Sukontason KL, Piangiai S, Boonchu N, Chaiwong T, Vogtsberger RC (2003) Mouthparts of Megaselia scalaris (Loew) (Diptera: Phoridae). Micron 34 (8):345-350. https://doi.org/https://doi.org/10.1016/j.micron.2003.08.003

Sukontason K, Sukontason KL, Piangjai S, Choochote W, Vogtsberger RC (2005) Ultrastructure of the ommatrichia in Megaselia scalaris (Loew) (Diptera: Phoridae). Micron 36:191-194

Sukontason KL, Sukontason K, Lertthamnongtham S, Boonchu N (2002) Surface ultrastructure of third-instar Megaselia scalaris (Diptera: Phoridae). Mem Inst Oswaldo Cruz 97:663-665

Tara JS, Sharma M (2010) Record of Hemipteran insect pest diversity on Murraya koenigii (L.) Sprengel (Curry Leaf), a medicinally important plant from Jammu and Kashmir State. The Bioscan 5(1):71-74

Ulloa P, Hernandez M (1981) Biologia y control natural de Peridroma saucia, praga de la flor de la curuba. Rev Colomb Entomol 7:47-53

Varney RL, Noor MA (2010) The scuttle fly. Curr Biol 20(11):R466-R467. https://doi. org/https://doi.org/10.1016/..cub.2010.03.043

Wolf KW, Liu G (1996) Fine structure of the egg-shell in two humpbacked flies, Megaselia scalaris and Megaselia spiracularis (Diptera: Phoridae). Int J Insect Morphol Embryol 25:289-294

Zhang XS, Liu GC, Zhang DX, Shi CM (2017) Novel trophic interaction: the scuttle fly Megaselia scalaris (Diptera: Phoridae) is a facultative parasitoid of the desert scorpion Mesobuthus eupeus mongolicus (Scorpiones: Buthidae), J Nat Hist 51:1-2, 1-15. https://doi.org/https://doi.org/10.1080/00222933.2016. 1236222

\section{Publisher's Note}

Springer Nature remains neutral with regard to jurisdictional claims in published maps and institutional affiliations.

\section{Submit your manuscript to a SpringerOpen ${ }^{\circ}$ journal and benefit from:}

- Convenient online submission

- Rigorous peer review

- Open access: articles freely available online

- High visibility within the field

- Retaining the copyright to your article

Submit your next manuscript at $\boldsymbol{\nabla}$ springeropen.com 